\title{
Analysis of Temperature Variations, Types of Insulation and Coating on Corrosion Under Insulation on ASTM A53 Pipes
}

\author{
Reza Putra*, Muhammad, T Hafli, Nurul Islami, Arpan Apandi S \\ Department of Mechanical Engineering, Faculty of Engineering, Universitas Malikussaleh, Aceh, Indonesia \\ *Corresponding author E-mail: reza.putra@unimal.ac.id
}

Manuscript received 16 Nov 2021; revised 20 Nov 2021; accepted 1 Jan 2022. Date of publication 10 Jan 2022

\begin{abstract}
Corrosion Under Insulation (CUI) can be described as localized corrosion that forms as a result of the penetration of water or moisture through an insulating material. The pipe material used is of the ASTM A53 standard and the fluid used in seawater because almost all industries are located on the coast. This type of coating is carried out on the test pipe using Meiji Epoxy Filler. The test method is carried out by flowing seawater fluid in pipes with water temperature variations of $30^{\circ} \mathrm{C}, 50^{\circ} \mathrm{C}$, and $70^{\circ} \mathrm{C}$. This pipe varies the type of insulation by using glasswool and Rockwool (ASTM G 189-07). This insulation is conditioned in a wet state by giving 2 ml of seawater drops with a $\mathrm{pH}$ value of 4 per 6 hours. The test equipment is divided into 3 series according to temperature variations with 4 test specimens and 2 coating variations respectively. The test time was carried out for 336 hours to obtain the corrosion rate results using the ASTM G31-72 weight loss method. The results showed that the type of Glasswool insulation with specimens coated had the lowest corrosion rate value of $0.00483 \mathrm{mmpy}$ at a temperature of $30^{\circ} \mathrm{C}$ when compared to the same type of treatment on Rockwool insulation of $0.00724 \mathrm{mmpy}$ or an increase of 2.41 times. This study shows that the type of insulation, temperature variation, and coating greatly affect the rate of corrosion and the type of corrosion that occurs is uniform corrosion.
\end{abstract}

Keywords: Corrosion Under Insulation, Corrosion Rate, Glasswool, Rockwool, Coating.

\section{Introduction}

Corrosion is an event of damage that occurs to metals by chemical or electrochemical reactions to their environment. Corrosion can cause enormous cost losses in the construction of materials made of metal and non-metal [1] [2]. One of the most common types of corrosion is corrosion under insulation (CUI) [3]. Over the last 25 years, the problem of corrosion under insulation has been recognized by the chemical and petrochemical industries, leading to the need for effective corrosion protection for piping and equipment encased in insulation [4] [5] [6].

For example, in 2006 a petrochemical plant in the United States experienced a 4-inch leak in a hydrocarbon pipeline, the leak caused a large fire that destroyed half the unit and cost US \$50 million in losses, the cause of the leak was due to the CUI factor [7]. Corrosion under insulation (CUI) can be described as localized corrosion formed as a result of the penetration of water or moisture through the insulation material due to the presence of moisture in the insulation material [8]. Corrosion under insulation is a very serious problem for the oil and gas industry using piping systems [8] [7]. The most challenging problem of this type of corrosion is that the corrosion structure that occurs is not visible or covered by insulation, therefore to avoid corrosion so that it is not too severe choosing the type of insulation material is very important [9].

Conducted a study to analyze the type of insulation for the hot steam transmission pipe for a motorcycle tire cooker with a capacity of 2000 tires per day at PT. XYZ in Tangerang [9] [10]. In this study, quantitative methods were used to compare the types of insulation based on the existing theory of insulation conditions. There are several types of insulation compared in this study, namely rockwool, glasswool, and calcium silicate insulation. Based on the calculations that have been done, the data obtained regarding thermal conductivity (W/mK), minimum thickness $(\mathrm{mm})$, and heat transfer rate $(\mathrm{W} / \mathrm{m})$ that the type of insulation material Rockwool has the best ability is $0.032 \mathrm{~W} / \mathrm{mK}$, $10.6 \mathrm{~mm}$, and $52.95 \mathrm{~W} / \mathrm{m}$ compared to the types of insulation materials calcium silicate and Glasswool namely $0.056 \mathrm{~W} / \mathrm{mK}, 18.6 \mathrm{~mm}$ and $76.25 \mathrm{~W} / \mathrm{m}$ followed by $0.035 \mathrm{~W} / \mathrm{mK}, 11.6 \mathrm{~mm}$ and $56.41 \mathrm{~W} / \mathrm{m} \mathrm{[11].}$

Conducted a study to analyze boiler pipe insulation to minimize heat loss on the surface of the steam pipe in the Yarkasih cracker factory boiler. In this study, quantitative methods are used, usually measuring objective facts through concepts derived from variables and described in indicators by taking into account the reliability aspect. The method used to minimize heat loss is the insulation method on the steam pipeline. The insulation materials used are rockwool, glasswool, rockwool aluminum foil, glasswool aluminum foil, and glasswool rockwool. The results showed that the insulation with a thickness of $25 \mathrm{~mm}$ which had the smallest heat loss value was glasswool aluminum foil with a yield of $40.52 \mathrm{~W}$. There was a decrease in heat loss of $128.20 \mathrm{~W}(75.98 \%)$ from heat loss without insulation of $168.72 \mathrm{~W}$ [12]. 
Conducted a study to analyze the effect of materials on corrosion rates. In this study, there were three experiments carried out based on CUI simulation according to the ASTM G189-07 standard [12]. Experiments were carried out with three experimental methods by varying the insulation materials, namely Perlite, Calcium Silicate, and Rockwool. The results showed that Rockwool insulation material had the lowest corrosion rate of 0.086 mpy compared to the corrosion rate obtained using Perlite and Calcium Silicate insulation materials, respectively 2.56 mpy and 2.46 mpy. The main reason Rockwool reaches the lowest corrosion rate is that it has a high water absorption compared to Perlite and Calcium Silicate [13] [14].

The factors that lead to the occurrence of Corrosion Under Insulation (CUI) are due to water trapped in the insulation, a little oxygen that makes the humidity of the environment increase, there are gaps for corrosive substances to diffuse so that the corrosion rate is higher, and according to statistics, the main factors for Corrosion Under Insulation ( CUI) is caused by the selection of insulation material and improper installation of insulation. Therefore, to find out the problems above, this research needs to be carried out to find out more about the problem of corrosion under insulation (CUI) while minimizing problems and losses that occur for industrial companies. In this study, we will look for the speed of the corrosion rate that occurs in pipes wrapped in insulation by using different types of insulation and also using a pipe coating layer that can inhibit the corrosion rate [4] [15] [16].

\section{Literature Review}

\subsection{Principle of Corrosion}

The corrosion reaction can be thought of as occurring by two simultaneous reactions of metal oxidation at the anode (corrosion end losing electrons) and depletion at the cathode (protected end-gaining electrons). For the reaction to occur, the following conditions must exist [17]:

1. A chemical potential difference must exist between locations adjacent to the metal surface

2. Electrolytes must be present to provide a conductivity solution and as a source of material to be reduced at the cathode.

3. To allow electrons to flow an electrical path through metals or between metals must be available.

\subsection{Calculation of Corrosion Rate}

The corrosion rate is the rate of destruction of a metal surface material caused by time. The rate of corrosion that occurs in different materials, as well as the way the attack is also different. The corrosion rate will be influenced by the resistance properties of a material with corrosive media. To make comparisons that occur, it can be done using a quantitative method of magnitude. The amount will be calculated using the weight lost on the specimen during the test.

The weight-loss method is a way to calculate the corrosion rate by measuring the weight loss of a material due to corrosion. The method used is by conducting a research period to get the value of weight loss due to corrosion that occurs.

In order to calculate the corrosion rate that occurs, the formula based on ASTM G31-72 is used as follows [7] [18]:

mpy $=(\mathrm{K} \times \mathrm{W}) /(\mathrm{A} \times \mathrm{T} \times \mathrm{D})$

Where :

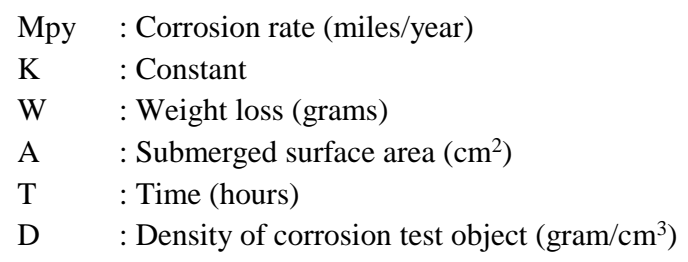

\subsection{Corrosion Test Standard Under Insulation}

Corrosion testing standards under insulation can be found in ASTM with the revision number G189 in 2007. This ASTM standard is the official guide for laboratory corrosion testing under insulation. These guidelines are generalized and can be carried out with variations in specifications in various materials, environments, and conditions depending on the desired experiment. However, there is limited research or implementation of this test using ASTM G189-07, and the analysis is generally limited to getting the corrosion rate only [16]. Thus, in this paper, ASTM G189-07 was applied to obtain the most influential factors in the incidence of CUI (Figure 1).

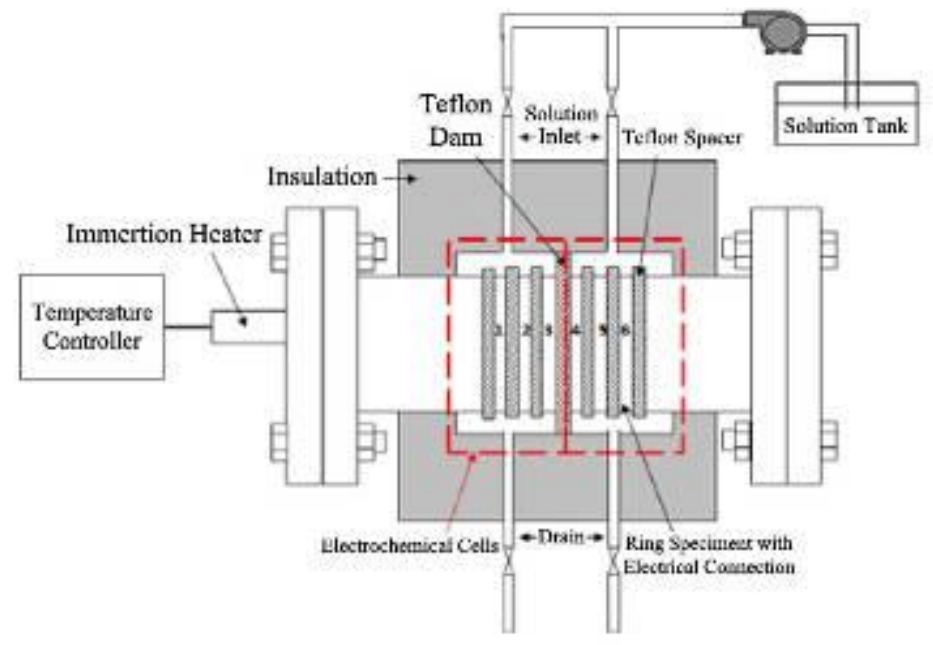

Fig 1. CUI Simulation Cell Schematic [13]. 


\subsection{Corrosion Under Insulation (CUI)}

Corrosion under insulation (CUI) is localized corrosion that attacks the metal interface between the metal surface and the insulation [19]. Corrosion Under Insulation (CUI) is a major problem related to unexpected factory failures in many factories today. A study shows that the highest leakage incidence in the chemical industry is due to the Corrosion Under Insulation (CUI) factor which causes a loss of about $40 \%$ to $60 \%$ of pipe maintenance costs [9] [20].

Corrosion under insulation refers to the external corrosion of piping and vessels made of carbon-manganese, low alloy, and austenitic stainless steels that occur under the outer layer or jacketed insulation due to water penetration. Due to its nature, CUI tends to remain undetected until the coating insulation is removed to allow inspection or when a leak to the atmosphere occurs. CUI is a major common problem worldwide occurring in all refining, petrochemical, power, industrial, onshore and offshore industries. This is not a new problem, but it could be a serious problem. CUI has been responsible for many major leaks leading to health and safety incidents, resulting in production losses, and is responsible for the large maintenance budget required to mitigate these problems. Figure 2 . shows the condition of the pipe corroded under insulation [21].

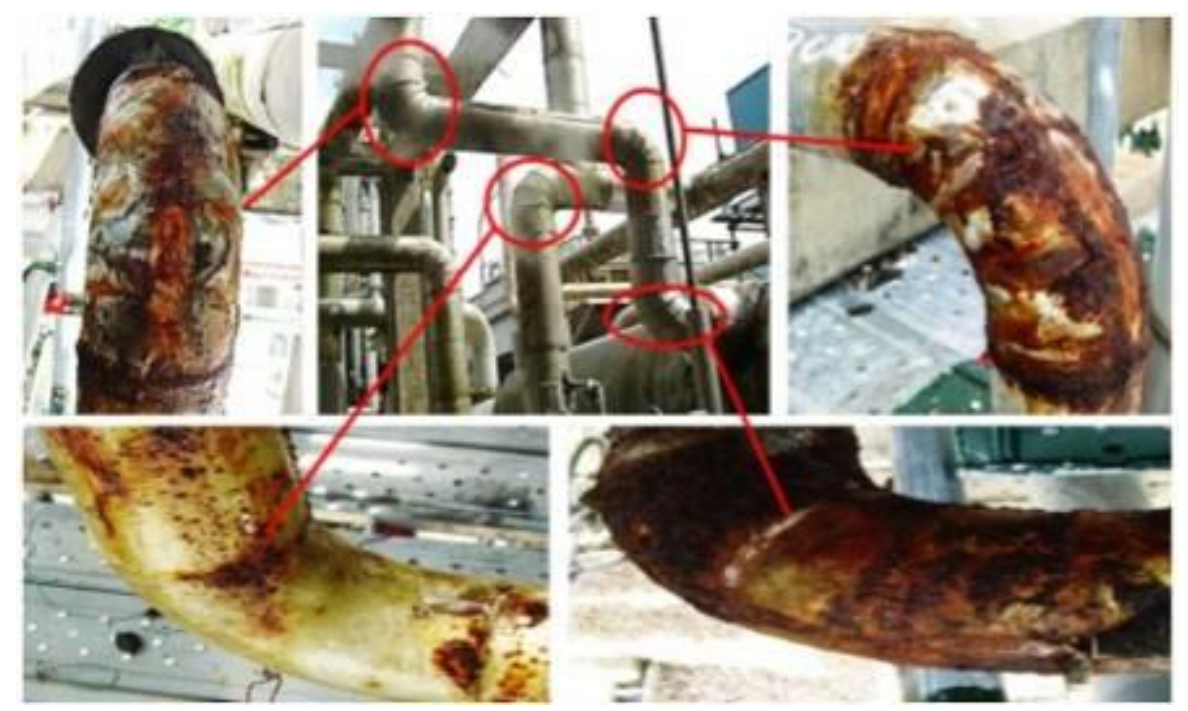

Fig 2. Corrosion Under Insulations [19]

Factors that can affect the occurrence of corrosion under insulation are as follows:

1. Water

Due to system leaks, ineffective water retention, and less than optimal maintenance, water can enter during the insulation work process or installation.

2. Chemical Content in Water

One of the factors in the chemical content in the water that can accelerate the occurrence of corrosion is a decrease in $\mathrm{pH}$, such as acid corrosion which generally occurs in carbon steel materials.

3. Temperature

Two ways can affect the temperature of atmospheric corrosion, namely:

a. An increase in the rate of a reaction occurs with an increase in temperature. With service temperatures in-between $0^{\circ} \mathrm{C}$ and $100^{\circ} \mathrm{C}$ $\left(32^{\circ} \mathrm{F}\right.$ and $\left.212^{\circ} \mathrm{F}\right)$ the water is likely still in a liquid state. With this average temperature, each increase in temperature the corrosion rate doubles from $15^{\circ} \mathrm{C}$ to $20^{\circ} \mathrm{C}\left(27^{\circ} \mathrm{F}\right.$ to $\left.36^{\circ} \mathrm{F}\right)$. The maximum ability to corrosion generally lies between these two averages. Chloride-induced stress corrosion cracking in carbon steel materials generally occurs in the ambient range or below $120^{\circ} \mathrm{C}\left(248^{\circ} \mathrm{F}\right)$.

b. Changes that occur in temperature affect the relative humidity which can cause condensation at the dew point condensation. When the temperature drops below the dew point, the air becomes dense (saturated) with droplets of water or water vapor falling on the exposed surface. On all sufficiently cool surfaces, condensation may occur, both inside and outside the insulation. Water can stagnate in certain places and create an invisible electrolyte pool container in a hidden place in a structure so that unexpected places corrosion can occur. 


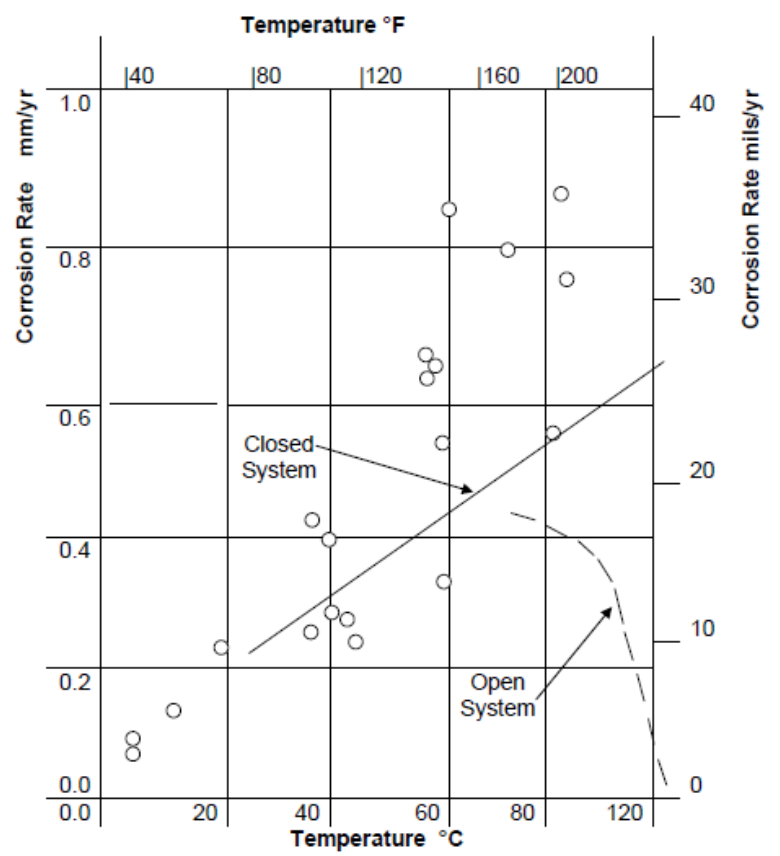

Fig 3. The graph of the relationship between corrosion rate and temperature.

Figure 3. It can be seen that the relationship between the corrosion rate and temperature, the difference that occurs is more focused on the difference in the system, namely an open and closed system. To make it more clear, see the explanation below:

1. Open System

In this system, it is known that with increasing temperature, the corrosion rate will also increase but eventually it will decrease again. In this event, the remaining water will evaporate so that in the water system nothing is trapped.

2. Closed System

In contrast to a closed system, this system when the temperature increases, the corrosion rate increases or it can be said that the corrosion rate is proportional to the temperature. Because in this event the water is trapped in the system at the same time it cannot evaporate completely.

\subsection{Types of Insulating Materials}

The insulation materials that will be used in this research are Glasswool and Rockwool insulation materials.

a. Glasswool

Glasswool is a damping material formed from glass fiber which is made to resemble wool [20]. Glasswool is made in rolls and sheets. With density or density and certain specifications or processes. Glasswool began to be made from the process of mixing materials from recycled glass at a temperature of $1450^{\circ} \mathrm{C}$ and natural sand. The resulting glass is converted into a fiber. The mechanical strength and cohesion of the results were obtained from the results of the presence of a mixture of fiber and cement together. Between fiber intersections, there must be a chemical mixture. The fiber sheet is then heated at a temperature of about $200^{\circ} \mathrm{C}$ to combine with additional resin and thereafter stored for a specified time to achieve stability and strength.

The last process is cutting wool sheets and wrapping them in sheets or rolls at not too high pressure before they are prepared for packaging and after that, they are distributed. Glasswool is a good sound insulation material made from a combination of flexible glass fiber and chemicals, which can retain air and produce a low density or density that can be adjusted according to the bond and pressure are given.

b. Rockwool

Rockwool is an insulation material, including a type of thermal insulation [21]. Made of lightweight fiber mine with a core of natural stone combined with hot resin. The raw material consists of volcanic rock or basalt, which producers place in furnaces. The rocks are melted until the material becomes lava. The lava is then blown into a rotating chamber, which pulls the lava into fibers. The fibers are then collected and compressed and the density and overall structure of the Rockwool are adjusted. When the Rockwool has gone through a curing treatment oven, the wool is cut into sheets and cubes. While some insulation is cut for pipe insulation, other types are cut for residential purposes. Rockwool insulation consists of at least $95 \%$ rock wool and has a melting point above $1,000^{\circ} \mathrm{C}$. Due to its non-combustibility it does not contribute to the fire load in the building. As a result, using Rockwool insulation products in buildings makes it possible to increase fire safety, due to their fire-resistant characteristics.

Rockwool is a thermoset polymer made from the reaction between a diisocyanate compound and a polyfunctional compound containing several hydroxyl functional groups (polyols). Polyurethane has many functions which are about $70 \%$ used as foam. Elastic polyurethane foam is used as an insulator, including textile laminates for winter clothing. 


\section{Methods}

\subsection{Specification ASTM A53}

The steel specimen used in this research is ASTM A53 carbon steel pipe. Where the steel pipe has a carbon content of $0.30 \%$, as can be seen in Table 1 below

Table 1. Specifications and Composition of ASTM A53 Carbon Steel

\begin{tabular}{ccccc}
\hline Outer Diameter & \multicolumn{1}{c}{ Inner Diameter } & Length & $30 \mathrm{~mm}^{\mathbf{m}}$ \\
\hline $\mathbf{7 3} \mathbf{~ m m}$ & $\mathbf{M n}$ & $67 \mathrm{~mm}$ & $\mathbf{S}$ & $\mathbf{C u}^{\mathbf{A}}$ \\
\hline $\mathbf{C}$ & $1,20 \%$ & $\mathbf{P}$ & $0,045 \%$ & $0,40 \%$ \\
\hline $\mathbf{0 , 3 0} \%$ & $\mathbf{C r}^{\mathbf{A}}$ & $\mathbf{M o}^{\mathbf{A}}$ & $\mathbf{V}^{\mathbf{A}}$ & $0,8 \%$
\end{tabular}

${ }^{\mathrm{A}}$ The combination of these five elements should not exceed $1.00 \%$

Simple drawings for the dimensions of this pipe can be seen in Figure 4. and Figure 5. as follows.

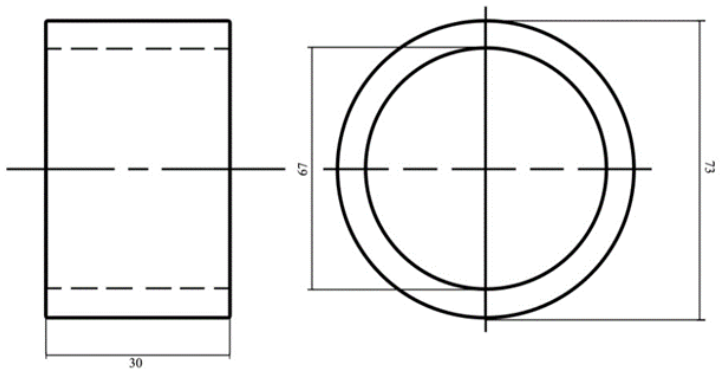

Fig 4. Pipe Dimensions

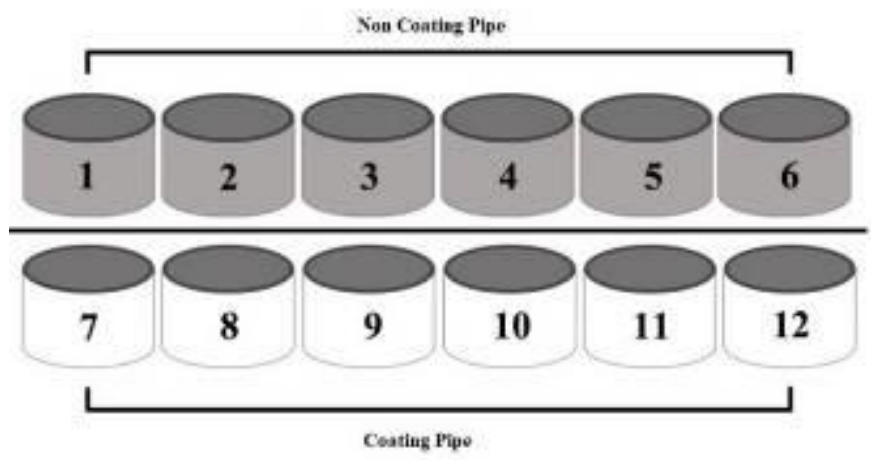

Fig 5. Pipe preparation with and without coating

ASTM A53 steel pipe was cut into test specimens with a width of $30 \mathrm{~mm}$ using a band saw. The 12 piece test specimens were cleaned thoroughly according to ASTM G1-03. In this test, a comparison is made between the coated and uncoated test specimens. Coating of specimens using paint with Meiji Epoxy Filler paint. The painting was done using a spray gun at distance of $25-30 \mathrm{~cm}$ and a speed of $25-40 \mathrm{~cm} / \mathrm{second}$ from the surface of the specimen. In this test the thickness of the coating ranged from $290 \mathrm{~m}-410 \mathrm{~m}$ refer to ASTM D 1186. The results of the measurement of paint thickness after drying were carried out according to the standard ASTM D 1005. Some of the test specimens were installed with Rockwool insulation and the other half were fitted with glasswool with the same area and length as the specimen. All test specimens that have been insulated are coated with aluminum as packaging.

\subsection{Testing With Standard ASTM G189-07}

This Corrosion Under Insulation study uses the ASTM G189-07 Standard. This standard is applied to obtain the most influential factors in the incidence of CUI, namely the type of material, the influence of temperature, environment, and certain conditions, depending on the desired experiment. The pipe-shaped test specimens were grouped into 3 variations of the internal temperature test of the water fluid in the pipe, namely 30,50 , and $70^{\circ} \mathrm{C}$. The test equipment for each temperature variation has four specimens. Of the four specimens, they were divided into two with Rockwool and Glasswool insulation types, in each type of insulation there were coated and non-coated specimens. In the test box, the water fluid is heated according to temperature variations with the help of a heater and thermostat controller so that the temperature in the test box remains constant. The water fluid in the reserve tank is also prepared to have flowed through the hose to the circuit box (Figure 6.). This insulation is conditioned in a wet state by providing drops of water with a pH value of 4.

The series of tests were carried out for 336 hours so that the research did not take a long time because this research method was used for laboratory corrosion experiments under insulation. Every 6 hours the insulation is moistened with $2 \mathrm{ml}$ of water to keep it moist so that corrosion continues. After 336 hours the test circuit is dismantled and the pipe condition should be as it was when the initial weighing was carried out. 


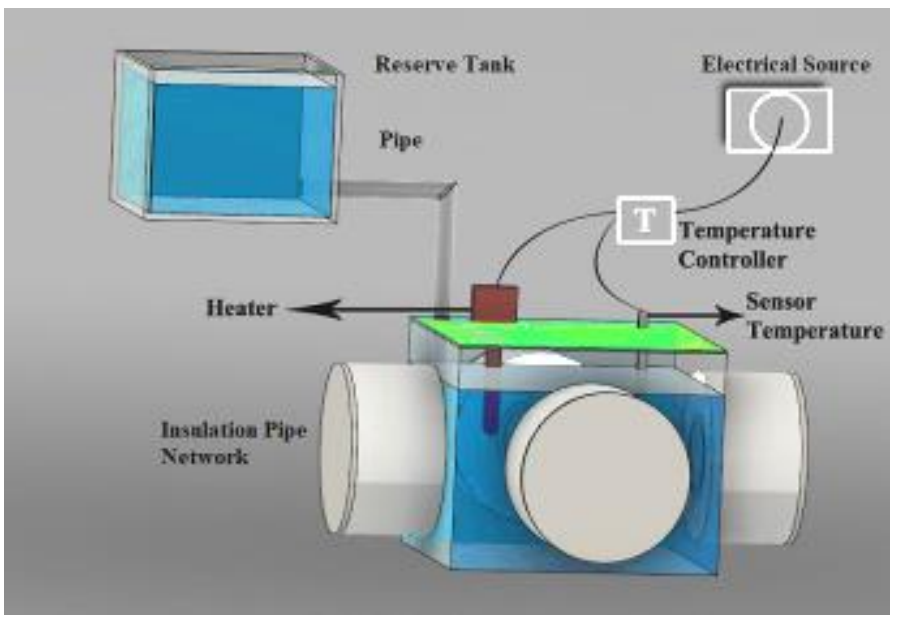

Fig 6. The design of the experimental circuit

\section{Result and Discussion}

In general, Corrosion Under Insulation occurs due to the presence of water dew. Like rainwater, cleaning splashes and leaks can cause corrosion. The types of corrosion in corrosion under insulation are uniform corrosion, pitting corrosion and stress cracking corrosion, and in this study the only type of corrosion that occurred was uniform corrosion.

The results of the research obtained after it was carried out showed that the type of corrosion was evenly distributed. This type of corrosion occurs evenly on the outer surface of the pipe which is coated with insulation, this type of corrosion can occur due to electrochemical reactions and low $\mathrm{pH}$ of water and moist air due to the outer surface of the pipe. Seawater used as a corrosive medium has a $\mathrm{pH}$ value of 4 and belongs to the acid category. Figure 7 shows the difference in uniform corrosion of corroded pipes under insulation.

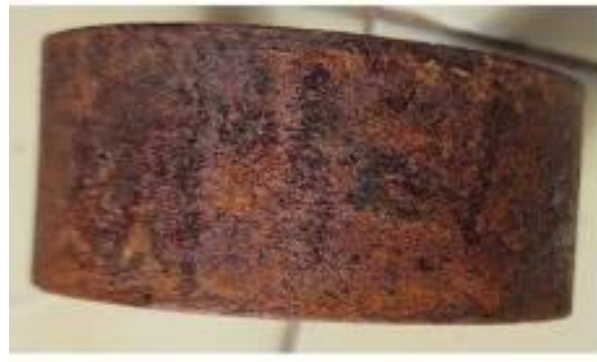

(a)

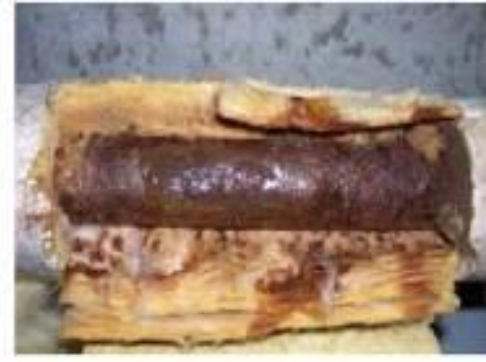

(b)

Fig 7. Corroded pipe under uniform corrosion type insulation (a) Result of research ; (b) Sulardi Research [26]

The outer surface of the carbon steel pipe was examined using a 100x Digital Microscope camera to see and observe the shape of the corrosion. The following are the results of micro photos on non-coated and coated Glasswool material. Figure 8. below is the result of observations on pictures of non-coating pipes that are insulated with glasswool.

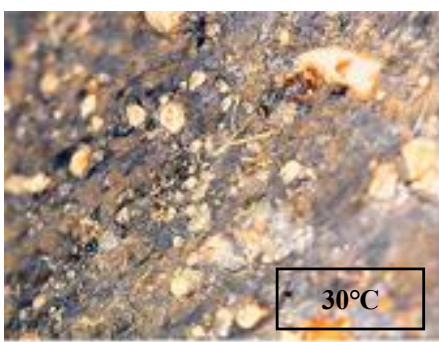

(a)

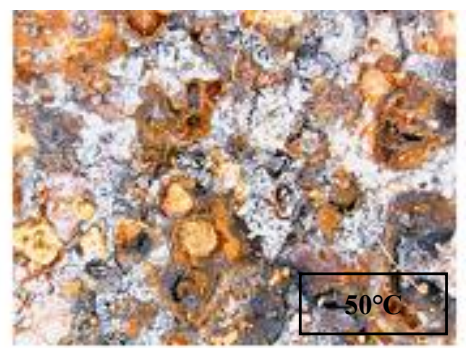

(b)

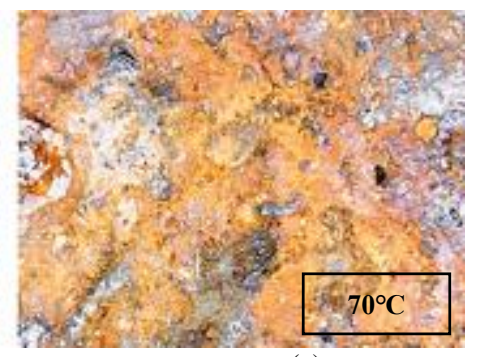

(c)

Fig 8. 100x magnification of a glasswool-insulated non-coated pipe

(a), (b) and (c) uniform corrosion.

Figure 8. (a), (b), and (c) show that the three images are the results of the 336-hour test on the ASTM A53 pipe which is insulated with Glasswool at temperatures of $30^{\circ} \mathrm{C}, 50^{\circ} \mathrm{C}$, and $70^{\circ} \mathrm{C}$ non-coating. The type of Uniform Corrosion can be well-identified because of its comprehensive and uniform attack appearance on all metal surfaces. This corrosion occurs if the corrosive environment has equal access to all parts of the metal surface and the metal must have the same chemical composition thermodynamically. However, this condition does not generally apply. In general, this uniform corrosion does not have good self-protective properties, so that the corrosion mechanism in all places proceeds without significant obstacles.

The results of the observations on the picture of the pipe in the glasswool insulated coating are shown in Figure 9. 


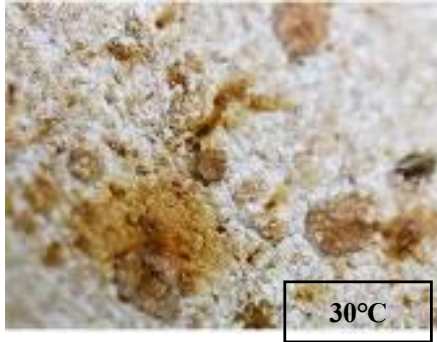

(a)

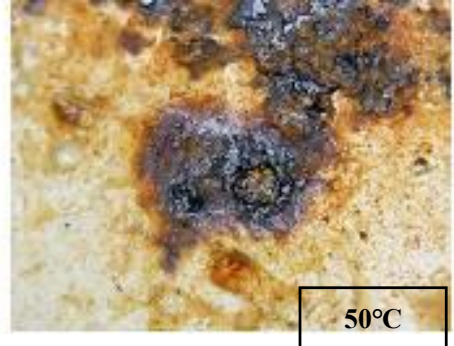

$50^{\circ} \mathrm{C}$

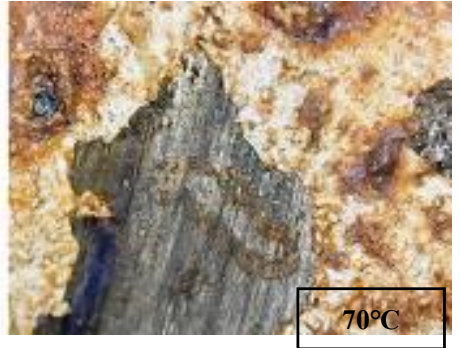

(b)

(c)

Fig 9. 100x magnification of the pipe in the Glasswool insulated coating

(a) Corrosion products; (b) uniform corrosion; (c) Peeling off the coating

In Figure 9 (a), the test specimen with a temperature of $30^{\circ} \mathrm{C}$ shows the appearance of corrosion products on the pipe surface, which is a common type of uniform corrosion that occurs on metal surfaces. Figure b) $50^{\circ} \mathrm{C}$ shows that uniform corrosion occurs but the growth is more. Corrosion occurs simultaneously on the entire metal surface, therefore the metal that undergoes corrosion evenly will experience a relatively large reduction in dimensions per unit time. Figure c) $70^{\circ} \mathrm{C}$ shows that the result of high water temperature causes damage to the coating layer so that the corrosion that occurs in the pipe goes directly to the outer surface layer of the pipe, causing an abnormal corrosion rate.

In pipe specimens carried out during testing with coating treatment, there is still corrosion that occurs even though the corrosion rate is still much lower than non-coated pipes. This is because there is still damage that occurs in the coating layer.

The results of observations on non-coating pipes that are insulated with rockwool are shown in Figure 10.

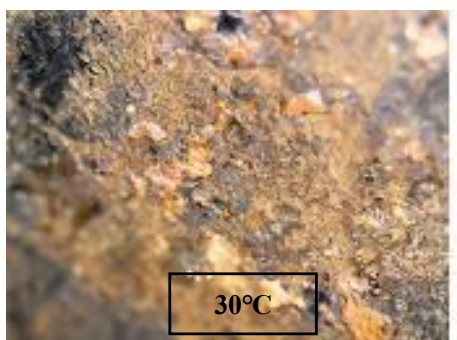

(a)

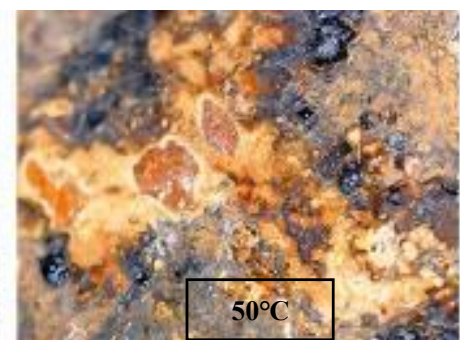

(b)

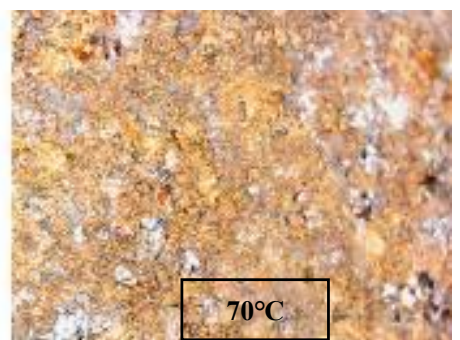

(c)

Fig 10. Observation with 100x magnification on non-coated pipe insulated Rockwool

(a), (b) and (c) uniform corrosion.

Based on the characteristics of the damage in Figure 10, namely, Figure a) $30^{\circ} \mathrm{C}$ indicates that the type of corrosion that occurs is uniform corrosion with the same intensity. In picture b) $50^{\circ} \mathrm{C}$ above also still shows the type of uniform corrosion. Uniform corrosion occurs as a result of a chemical reaction due to the low $\mathrm{pH}$ of the water and the moist air on the specimen surface. In Figure c) $70^{\circ} \mathrm{C}$, it can be seen that the type of corrosion that occurs is uniform corrosion with uniform size, this is due to the anodic and cathodic processes that take place on the pipe surface that moves evenly. the influence of a wet insulation environment causes the outer surface of the pipe to be susceptible to corrosion.

Observation of the pipe in the Rockwool insulated coating after the corrosion test is carried out is shown in Figure 11.

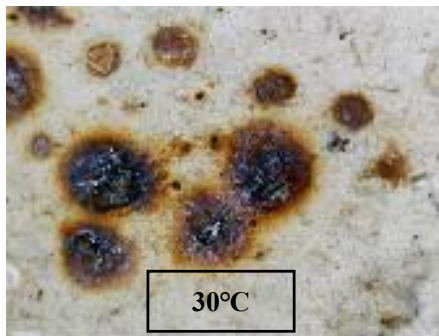

(a)

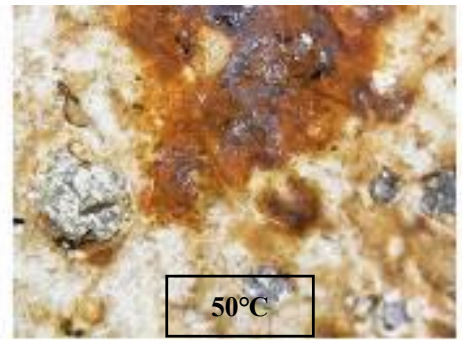

(b)

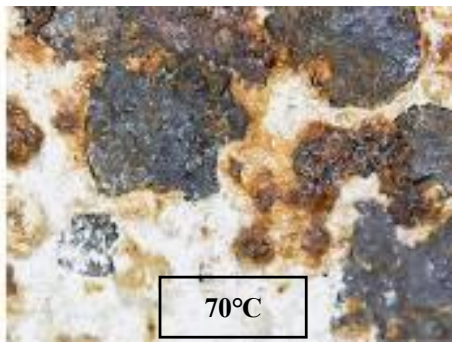

(c)

Fig 11. Observations of 100x magnification on the pipe in the Rockwool insulated coating

(a) corrosion products; (b) uniform corrosion; (c) peeling off the coating

(b)

Figure 11, which is in Figure a) $30^{\circ} \mathrm{C}$ shows the occurrence of uniform corrosion were in this case what is happening is still forming corrosion products or the initial process of uniform corrosion. In figure b) $50^{\circ} \mathrm{C}$ shows uniform corrosion on the outer surface of the coated pipe. And at c) $70^{\circ} \mathrm{C}$ indicates that there is peeling of the coating on some of the outer surface of the pipe, this is because the nature of the coating will fail if the coating is under stress. Stress is meant here not only from the physical form of mechanics that can cause deformation. Anything that can degrade or attack the integrity of the coating can also be called stress.

An example in this research case is the coating that coats the pipe in direct contact with seawater, where in general seawater has a low acid content and on the inner surface of the pipe it is in direct contact with normal water which has a temperature of $30^{\circ} \mathrm{C}, 50^{\circ} \mathrm{C}$, and $70^{\circ} \mathrm{C}$. Water is a small molecule that can move through the coating at a different rate for each coating. If there is a substance that can dissolve in water between the coating substrate and the coating or the primary coating then the situation can change dramatically. The fluid will undergo movement into the coating and come into direct contact with the species and dissolve it.

The corrosion rate is the rate of destruction of a metal surface material caused by time. The rate of corrosion that occurs in different materials, as well as the way the attack is also different. The corrosion rate will be influenced by the resistance properties of a material with corrosive media. The weight-loss method is a way to calculate the corrosion rate by measuring the weight loss of a material due to corrosion 
that occurs. The method used is by conducting a research period to get the value of weight loss due to corrosion that occurs. The results of the calculation of the corrosion rate in each variation, a graph is obtained that shows the correlation between each temperature variation and the variation of the type of insulation.

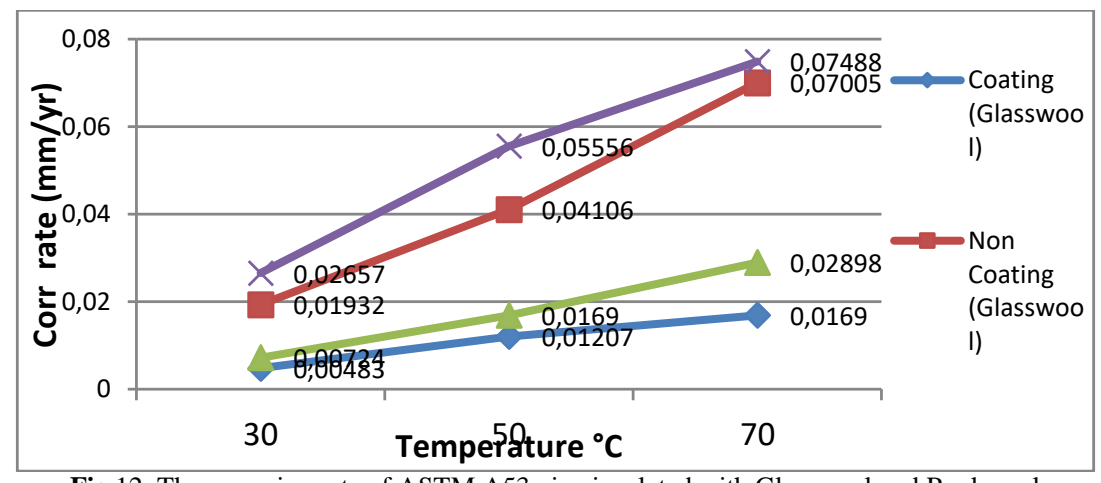

Fig 12. The corrosion rate of ASTM A53 pipe insulated with Glasswool and Rockwool

The graph in Figure 12. Shows the comparison of test specimens using two types of insulation, namely Glasswool and Rock-wool, with temperature variations of $30^{\circ} \mathrm{C}, 50^{\circ} \mathrm{C}$, and $70^{\circ} \mathrm{C}$. This graph also represents the average value of the test specimens that have been coated or not. The graph shows the highest corrosion rate occurs in the type of Rockwool insulation at each temperature of each non-coated specimen. This is because the type of Rockwool insulation used has a high water absorption capacity so that the water in the initial layer of insulation is directly absorbed into the pipe surface layer. The corrosion rate of pipes coated with different types of insulation, Rockwool, and glasswool, showed a significant difference at a temperature of $70^{\circ} \mathrm{C}$ with a corrosion rate of 0.07488 mmpy for non-coated rockwool insulation when compared to non-coated glass-wool at the same temperature, of 0.07005 . mpy. The results of this weightloss study prove the NACE International theory which states that for every increase in temperature that occurs at $15^{\circ} \mathrm{C}$ to $20^{\circ} \mathrm{C}\left(27^{\circ} \mathrm{F}\right.$ to $\left.36^{\circ} \mathrm{F}\right)$, the corrosion rate will increase twice as much as before. The maximum ability to corrosion generally lies between these two averages. The lowest corrosion rate occurred in specimens coated with glasswool at a temperature of $30^{\circ} \mathrm{C}$ at $0.00483 \mathrm{mmpy}$. This value was $0.241 \%$ lower than the specimens coated with rockwool coating.

The level of resistance of a material to corrosion generally has a corrosion rate value between 1-200 mpy. Table 2 . shows the level of resistance of a material based on its corrosion rate.

Table 2. The level of resistance of a material based on its corrosion rate

\begin{tabular}{cccccc}
\hline \multirow{2}{*}{$\begin{array}{c}\text { Relative corro- } \\
\text { sion resistance }\end{array}$} & \multicolumn{5}{c}{ Approximate metric equivalent } \\
\cline { 2 - 6 } & Mpy/year & $\mu m / y e a r$ & $n m / h r$ & $p m / s e c$ \\
\hline Outstanding & $<1$ & $<0,02$ & $<25$ & $<2$ & $<1$ \\
\hline Excellent & $1-5$ & $0,02-0,1$ & $25-100$ & $2-10$ & $1-5$ \\
\hline Good & $5-20$ & $0,1-0,5$ & $100-500$ & $10-50$ & $5-20$ \\
\hline Fair & $20-50$ & $0,5-1$ & $500-1000$ & $50-150$ & $20-50$ \\
\hline Poor & $50-200$ & $1-5$ & $1000-5000$ & $150-500$ & $50-200$ \\
\hline Unacceptable & $200+$ & $5+$ & $5000+$ & $500+$ & $200+$ \\
\hline
\end{tabular}

Based on the results of research that has been carried out for 336 hours, it shows that the corrosion rate can be entered into 2 parts, namely outstanding and excellent. The outstanding part is the entire temperature for the coated glasswool insulation and the $30^{\circ} \mathrm{C}$ and $50^{\circ} \mathrm{C}$ temperatures for the coated rockwool insulation. The excellent part is the entire temperature of the non-coated glasswool and rockwool insulation and the temperature of $70^{\circ} \mathrm{C}$ for the coated rockwool insulation.

\section{Conclusion}

The results showed that the type of Glasswool insulation with coated specimens had the lowest corrosion rate value, namely $0.00483 \mathrm{mmpy}$ at a temperature of $30^{\circ} \mathrm{C}$. This value when compared with the same type of treatment on Rockwool insulation which has a value of 0.00724 mmpy has a comparison of 2.41 times. This study shows that the type of insulation, temperature variations and coating greatly affect the speed of the corrosion rate and the type of corrosion that occurs in general in this test is the type of uniform corrosion that attacks the surface of the insulated metal.

\section{Acknowledgment}

The authors would like to thank Rector, Dean of Engineering Faculty and Research institutions and community service (LPPM) Universitas Malikussaleh, who have funded this research with no. 19/PPK-2/SPK-JL/2021.

\section{References}

[1] S. Nova and N. Misbah, "Analisis Pengaruh Salinitas dan Suhu Air Laut Terhadap Laju Korosi Baja A36 pada Pengelasan SMAW," J. Tek. Its, vol. 1, no. 1, 2012.

[2] S. Ali Rafsanjani, F. E. Rooslan Santosa, and R. Durrotun Nasihien, "Analysis of Planning for Clean Water Needs at Grand Sagara West Surabaya Hotel With the Green Buillding Concept," Int. J. Eng. Sci. Inf. Technol., vol. 1, no. 2, 2021, doi: 
10.52088/ijesty.v1i2.55.

[3] M. G. Fontana, "Corrosion engineering. Third edition.," 1986.

[4] A. Fried, "Concrete," in Materials Science in Construction: An Introduction, 2014.

[5] D. H. Ling Lim and D. E. Gunister, "Awareness of corrosion importance among engineering undergraduates in the United Arab Emirates,” Educ. Res., vol. 09, no. 02, 2018, doi: 10.14303/er.2018.018.

[6] "Correction to: Modelling durability of reinforced concrete structures (Corrosion Engineering, Science and Technology, (2020), 55, 2, (71-181), 10.1080/1478422X.2019.1710660)," Corrosion Engineering Science and Technology, vol. 55, no. 4. 2020, doi: 10.1080/1478422X.2020.1766776.

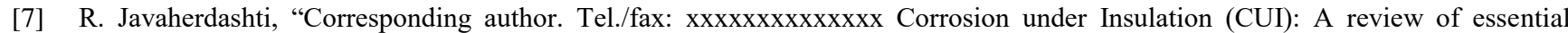
knowledge and practice," J. Mater. Sci. Surf. Eng., vol. 1, no. 2, 2014.

[8] R. Javaherdashti, "Corrosion under Insulation (CUI): A review of essential knowledge and practice," J. Mater. Sci. Surf. Eng., vol. 1, no. 2, 2014.

[9] E. Eltai, K. Al-Khalifa, A. Al-Ryashi, E. Mahdi, and A. S. Hamouda, "Investigating the corrosion under insulation (CUI) on steel pipe exposed to Arabian Gulf sea water drops," in Key Engineering Materials, 2016, vol. 689, doi: 10.4028/www.scientific.net/KEM.689.148.

[10] T. Dickson and S. Pavía, "Energy performance, environmental impact and cost of a range of insulation materials," Renew. Sustain. Energy Rev., vol. 140, 2021, doi: 10.1016/j.rser.2021.110752.

[11] M. Gonçalves, N. Simões, C. Serra, and I. Flores-Colen, "A review of the challenges posed by the use of vacuum panels in external insulation finishing systems," Applied Energy, vol. 257. 2020, doi: 10.1016/j.apenergy.2019.114028.

[12] D. Kumar, P. X. W. Zou, R. A. Memon, M. M. Alam, J. G. Sanjayan, and S. Kumar, "Life-cycle cost analysis of building wall and insulation materials," J. Build. Phys., vol. 43, no. 5, 2020, doi: 10.1177/1744259119857749.

[13] A. Nerlich and D. Dannehl, "Soilless Cultivation: Dynamically Changing Chemical Properties and Physical Conditions of Organic Substrates Influence the Plant Phenotype of Lettuce," Front. Plant Sci., vol. 11, 2021, doi: 10.3389/fpls.2020.601455.

[14] A. Komosa, B. Markiewicz, T. Kleiber, E. Mieloszyk, and M. Mieloch, "Yield and nutrient status of greenhouse tomato (Lycopersicon esculentum mill.) grown in new and re-used rockwool, polyurethane, nft and aeroponics," J. Elem., vol. 25, no. 2, 2020, doi: 10.5601/jelem.2019.24.3.1894.

[15] M. Olivia and H. Nikraz, "Properties of fly ash geopolymer concrete designed by Taguchi method," Mater. Des., 2012, doi: 10.1016/j.matdes.2011.10.036.

[16] J. Xiao, C. Qiang, A. Nanni, and K. Zhang, "Use of sea-sand and seawater in concrete construction: Current status and future opportunities," Construction and Building Materials. 2017, doi: 10.1016/j.conbuildmat.2017.08.130.

[17] M. N. Al Dahlan, M. A. Obied, K. M. Marshad, F. M. Sahman, I. S. Yami, and A. M. Alhajri, "Evaluation of synthetic acid for wells stimulation in carbonate formations," in Society of Petroleum Engineers - SPE Middle East Unconventional Resources Conference and Exhibition 2015 - The Journey of Unconventional Resources: From Exploration to Successful Development, 2015, doi: 10.2118/172945-ms.

[18] B. N. Popov, Corrosion Engineering: Principles and Solved Problems. 2015.

[19] A. Marquez, J. Singh, and C. Maharaj, "Corrosion Under Insulation Examination to Prevent Failures in Equipment at a Petrochemical Plant," J. Fail. Anal. Prev., vol. 21, no. 3, 2021, doi: 10.1007/s11668-021-01135-5.

[20] E. O. Eltai, F. Musharavati, and E. S. Mahdi, "Severity of corrosion under insulation (CUI) to structures and strategies to detect it," Corrosion Reviews. 2019, doi: 10.1515/corrrev-2018-0102.

[21] Y. H. Tsai, J. Wang, W. T. Chien, C. Y. Wei, X. Wang, and S. H. Hsieh, "A BIM-based approach for predicting corrosion under insulation," Autom. Constr., vol. 107, 2019, doi: 10.1016/j.autcon.2019.102923. 